Tremblay, J. A., M. Robert, D. P. Hynes, M. A. Young, and B. Drolet. 2018. Range extension of the threatened Red Crossbill (Loxia curvirostra percna) in Canada: new insights from Anticosti Island, Québec. Avian Conservation and Ecology 13(1):10. https://doi.org/10.5751/ACE-01175-130110 Copyright (C) 2018 by the author(s). Published here under license by the Resilience Alliance.

Research Paper

\title{
Range extension of the threatened Red Crossbill (Loxia curvirostra percna) in Canada: new insights from Anticosti Island, Québec
}

\author{
Junior A. Tremblay ${ }^{1}$, Michel Robert ${ }^{2}$, Douglas P. Hynes ${ }^{3}$, Matthew A. Young ${ }^{4}$ and Bruno Drolet ${ }^{2}$ \\ ${ }^{1}$ Science and Technology Branch, Wildlife Research Division, Environment and Climate Change Canada, Québec, Canada, \\ ${ }^{2}$ Canadian Wildlife Service, Environment and Climate Change Canada, Québec, Canada, ${ }^{3}$ Canadian Wildlife Service, Environment \\ and Climate Change Canada, Dartmouth, Nova Scotia, Canada, ${ }^{4}$ Cornell Lab of Ornithology, Ithaca, New York, USA
}

\begin{abstract}
Red Crossbill (Loxia curvirostra percna; e.g., Type 8) is considered a distinctive taxonomic group likely restricted to the island of Newfoundland. Although it has been speculated that the percna subspecies may be extinct, recent works continue to show that Red Crossbills from insular Newfoundland are morphologically and vocally distinct. Large-billed Red Crossbills that may be percna have been observed outside Newfoundland and these sightings are likely due to movements of birds to the mainland during times of food shortages in their core range of occurrence. Red Crossbills had been previously detected on Anticosti Island, in 1963 and in the 1980s, but subspecies or vocal type identification was not attempted at that time. In recent years, regular sightings of large-billed Red Crossbills have been reported annually on Anticosti Island. Our main objectives with this study were to find Red Crossbills on Anticosti Island to (1) confirm the presence of percna by collecting vocal and morphological data, and (2) determine habitat associations of observed Red Crossbills. Morphometric and spectrographic analyses confirmed that some of the Red Crossbills present on Anticosti during our study were percna. Our results also suggest that the island may support breeding individuals of percna, which has direct consequences for the species' recovery capability, because it would increase the known population of this threatened species.
\end{abstract}

\section{Expansion de l'aire de répartition du Bec-croisé des sapins (Loxia curvirostra percna), une espèce menacée, au Canada : nouvelles découvertes provenant de l'île d'Anticosti, Québec}

RÉSUMÉ. Les Becs-croisés des sapins du type 8 (Loxia curvirostra percna) sont considérés comme un groupe taxonomique distinct, vraisemblablement limité à l'île de Terre-Neuve. Même s'il a été avancé que la sous-espèce percna pourrait être disparue, des travaux récents indiquent encore que les becs-croisés observés sur Terre-Neuve ont une morphologie et des vocalisations distinctes des autres sous-espèces. Des Becs-croisés des sapins munis d'un gros bec et appartenant peut-être à la sous-espèce percna ont été observés à l'extérieur de Terre-Neuve; ces observations sont probablement le fait d'oiseaux s'étant déplacés vers le continent lorsqu'une disette sévissait dans le coeur de leur aire de répartition. Des Becs-croisés des sapins ont déjà été repérés sur l'île d'Anticosti, en 1963 et dans les années 1980, mais aucune identification à la sous-espèce ou au type vocal n'avait alors été faite. Des observations régulières de Becscroisés des sapins à gros bec ont été rapportées chaque année sur cette île au cours des récentes années. Notre étude avait pour but de trouver des Becs-croisés des sapins sur Anticosti pour : 1) confirmer la présence de percna en amassant des données vocales et morphométriques; et 2) déterminer les habitats que fréquente cet oiseau sur cet île. Les analyses morphométrique et spectrographique ont confirmé que certains des becs-croisés présents sur Anticosti durant notre étude étaient des L. c. percna. Nos résultats indiquent aussi que cette île hébergerait peut-être des individus nicheurs de percna, possibilité qui a des conséquences directes sur le rétablissement de cette espèce menacée, puisque la taille de sa population serait alors plus grande que ce qu'on pense.

Key Words: conifer; crossbills; habitat association; morphometric; population dynamic; species at risk; species interactions; spectrographic analyses; vocalization; vocal type

\section{INTRODUCTION}

According to the ecological model of speciation, divergent natural selection drives the accumulation of differences, causing reproductive isolation among populations using different resources or occupying different habitats (Schluter 2001). North American Red Crossbills (Loxia curvirostra complex) are a group where divergent selection for foraging on alternative resources has been implicated in adaptive radiation and could potentially contribute to reproductive isolation (Benkman 1993, 1999, 2003, Benkman et al. 2001, Parchman and Benkman 2002). There are at least 10 Red Crossbill "vocal types" in North America (Young and Spahr 2017), which differ in morphology (e.g., bill size and palate structure; Benkman 1989, 1993, Groth 1993), genetics, ecological associations, and behavior (Groth 1993, Parchman et al. 2006, Young et al. 2012). Groth (1993) posited that each taxon gives a unique, identifiable call when in flight. Although this still has to be demonstrated, types may be reproductively isolated even when they are not geographically separated (Knox 1992, Groth 1993, Edelaar 2008, Benkman et al. 2009). Thus, it is hypothesized each of these types may represent a different incipient species (Parchman et al. 2006). In field and laboratory studies, Benkman et al. (2009) described a high level of reproductive isolation in Type 9 crossbills in sympatry with other call types (e.g., 2 and 5), either by field or laboratory observations. The Cassia Crossbill 
(Loxia sinesciuris; Type 9) is now recognized as a distinct species on the basis of differences in genetics, morphology, and behavior (Chesser et al. 2017).

The percna subspecies (i.e., Type 8) of the Red Crossbill is considered a distinctive taxonomic group likely restricted to insular Newfoundland (Bent 1912, Payne 1987, Groth 1993). Compared to other forms of North American Red Crossbills, percna is larger overall, with a larger bill and darker plumage (Bent 1912, Payne 1987, Groth 1993). Although it has been speculated that the percna subspecies may be extinct (Parchman and Benkman 2002, Benkman et al. 2008, Benkman 2010), recent works continue to show that Newfoundland crossbills are morphologically and vocally distinct (Young et al. 2012, Hynes and Miller 2014). Morphological measurements (bill depth and bill length) from Newfoundland birds $(n=5)$ are near those known for Type 8 (Young et al. 2012), and birds utter several unique call classes, which are presumed to be associated with percna (sensu Groth 1993).

As for other Red Crossbills subspecies, percna is a cone specialist seed-eater extremely specialized for foraging in coniferous habitat (Adkisson 1996). Past records of percna in Newfoundland are consistently reported in red pine (Pinus resinosa) stands, but very few of these stands remain these days (COSEWIC 2016). Hence, black and white spruce (Picea mariana and P. glauca, respectively) and tamarack (Larix laricina) are thought to be the most important food resources for crossbills in insular Newfoundland (Benkman 1989). Red squirrels (Tamiasciurus hudsonicus), introduced to insular Newfoundland in the 1960s (Payne 1976), are known to be important cone consumers (Smith 1968, 1970, Steele et al. 2005) and nest predators of birds (Reitsma et al. 1990, Darveau et al. 1997), and are thought to pose an important threat to percna (COSEWIC 2016). Further, competition for seeds between Red Crossbills and red squirrels is thought to be augmented by black spruce having reduced cone defenses, e.g., cones with more seeds, directed at squirrels due to its historical absence in Newfoundland (Parchman and Benkman 2002). Instead, Parchman and Benkman (2002) argue that the cone defenses observed in Newfoundland black spruce, e.g., increased scale thickness, are the result of a coevolutionary arms race between black spruce and percna that occurred during the last $9000 \mathrm{yr}$.

Observations of large-billed Red Crossbills outside Newfoundland, i.e., in Québec, Nova Scotia, and New Brunswick, that may be percna, are likely due to irruptions of birds to the mainland during times of food shortages in their core range of occurrence (Newton 1967, Smith and Balda 1979, Benkman 1987, Young and Spahr 2017). In Québec on Anticosti Island, Red Crossbills were detected during the 1984-1989 Québec Breeding Bird Atlas (Létourneau 1995), but subspecies identification was not attempted at that time. Since the early 2000s, regular sightings of large-billed Red Crossbills have been reported annually on Anticosti Island where red squirrel is absent.

The percna population on the island of Newfoundland is estimated to be 500-1500 individuals (COSEWIC 2016). If Red Crossbills of Anticosti Island comprise percna, it may have important implications concerning conservation and recovery of this threatened species by having the potential to increase its global population. Thus, the main objectives of this study were to confirm the presence of percna (Type 8) on Anticosti Island with vocal and morphological measurements, and to determine possible habitat associations of percna on the island.

\section{METHODS}

\section{Study area}

Anticosti Island is located in Québec in the Gulf of St. Lawrence (7943 km²; Fig. 1), and belongs to the eastern balsam fir (Abies balsamea)-paper birch (Betula papyrifera) bioclimatic region (Saucier et al. 1998). Approximately 200 white-tailed deer (Odocoileus virginianus) were introduced to Anticosti Island in the late 19th century. In the absence of large predators, the population rapidly increased, and densities now average $>20$ deer/ km (Rochette and Gingras 2007). Large deer populations have considerably modified the composition and structure of Anticosti forests: shrubs have been virtually eradicated, the understory is generally sparse and very open (Tremblay et al. 2005), and balsam fir-dominated stands have gradually been converted into white spruce stands (Potvin et al. 2003). Old forest stands (>90 yr) now constitute $\geq 50 \%$ of the landscape (Potvin et al. 2003).

Fig. 1. Study sites (recording and specimen collection sites represented by white and black circles, respectively) on Anticosti Island (Gulf of St. Lawrence, Québec, Canada) were affected by spruce budworm and were classified as having low (yellow), medium (orange), and high (red) levels of defoliation.

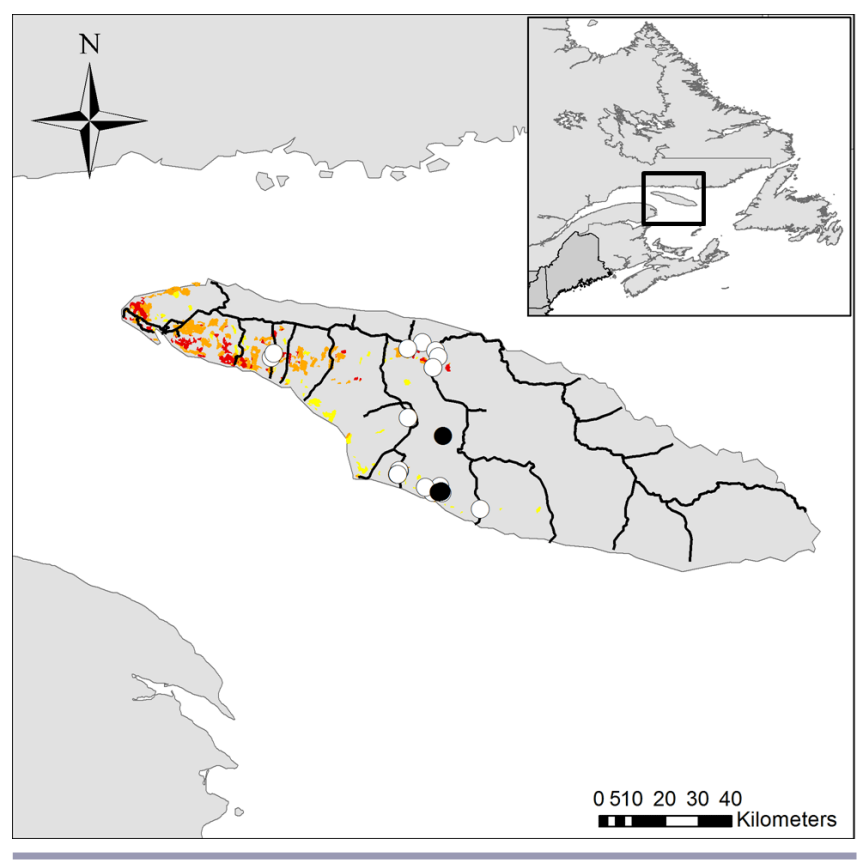

Principal natural disturbances in Anticosti Island are spruce budworm (Choristoneura fumiferana) and hemlock looper (Lambdina fiscellaria). The last spruce budworm outbreak occurred between 1975 and 1984; hemlock looper infestations last occurred in the early 1970s (Chouinard and Filion 2005). In 2012, new hemlock looper infestations were observed on Anticosti (MRNF 2012), and new defoliations associated with spruce budworm were reported in 2014 (MFFP 2015). 


\section{Data sampling}

Field data were collected from 8-16 July 2014 by two observers. We chose study sites based on a preliminary visit to the island in June 2014. Playbacks were played at each kilometer of forested roads for three minutes or when Red Crossbills were encountered. Vocalizations were recorded using a H2 Handy Recorder and a RODE NTG-2 microphone. When possible, we mounted the microphone on a 3-m pole to minimize the distance between the microphone and calling birds. Vocalizations were sampled at 44.1 $\mathrm{Hz}$ and digitized at 16 bits. Although flight calls given by an individual bird have been confirmed to be relatively stable over time (Sewall 2009, 2011), call types correspond with slight differences in morphology (Groth 1993, Benkman 1993, Parchman et al. 2006). To confirm the identity of percna, we attempted to collect both vocal and physical data from each individual by using mist nets and playbacks, but birds stayed above net height. Three birds (two adults and one juvenile) were collected with a Crosman Phantom rifle (Environment and Climate Change Canada Scientific permit SC-54), and have been given to the Canadian Museum of Nature.

\section{Acoustic analyses}

Class I and II calls (Hynes and Miller 2014; also known respectively as "flight" and "excitement" calls) have been recognized as type- or in the case of percna, subspecies specific crossbill calls (Groth 1993). Calls of Red Crossbills were first classified by type based on listening and visual assessments of spectrograms by D. Hynes and M. Young. Songs were also isolated for visual comparisons, although we acknowledge more study is needed on Red Crossbill song to determine if motifs can provide diagnostic cues for vocal type recognition. To compare quantitatively calls with those from Newfoundland, nine measurements were made on the fundamental frequency of Class I calls using Raven Pro 1.5 (Bioacoustics Research Program 2014). The selection of samples in time and frequency was guided using the Peak Frequency Contour (PFC) tool, which provides the peak frequency value for each spectral slice. Five acoustic measurements were computed directly from PFC values: the frequency at start, the frequency at end, the minimal frequency, the maximal frequency, and the mean frequency (Fig. 2). The last was computed as the sum of peak frequency values for all spectral slices divided by the total number of spectral slices. Three variables were based on $25 \%, 50 \%$, and $75 \%$ quantiles of energy distribution across calls to provide relatively robust acoustic measurements, i.e., less sensitive to variation in signal-to-noise ratio, reverberation, brightness and contrast settings, and human subjectivity). The variable "duration" was the period of time within a given selection (Fig. 2). Spectrograms were made with a 394 point $(8.93 \mathrm{~ms})$ Hann window $(3 \mathrm{~dB}$ bandwidth $=161 \mathrm{~Hz})$ with $94.4 \%$ overlap, and a 4096 point discrete Fournier transform, yielding time and frequency measurement precision of $0.0454 \mathrm{~ms}$ and $10.8 \mathrm{~Hz}$.

\section{Morphometric analyses}

Bill depth and bill length (upper mandible) were measured on the three individuals collected in 2014, and on 103 Red Crossbill specimens from the Canadian Museum of Nature. Museum specimens were collected mostly in June and July $(67 \% ; n=69)$, the same period of our field sampling. The museum specimens originated from diverse regions across Canada ( $n$ in parentheses):
British Columbia (29), Alberta (12), mainland Québec (26), Anticosti Island (2), Nova Scotia (5) and insular Newfoundland (29). We did a linear discriminant analysis (LDA; Izenman 2013) to predict a classification of red crossbills based on the combination of bill depth and bill length of each specimen using the function $l d a$ of the MASS package (Ripley et al. 2016). Also, in order to objectively evaluate the chance-corrected percentage of agreement between actual and predicted group memberships (agreement; Cohen 1960) of our LDA, we calculated the Cohen's kappa value $(\mathrm{K})$ using the function confusionMatrix of the CARET package (Kuhn et al. 2017). All statistical analyses were done in $\mathrm{R}$ v3.2.0 ( $\mathrm{R}$ core team 2015).

Fig. 2. Examples of the spectrographic variables used in the study. The fundamental frequency of a Class I call from a Type 8 Red Crossbill (Loxia curvirostra) recorded on Anticosti Island is shown. Variables were taken from the peak frequency contour (PFC; grey dashed lines) computed with Raven Pro 1.5. The variable Mean PFC was computed as the sum of PFC samples from all spectral slices divided by the total number of spectral slices. The variable "Duration" was derived from the selection box drawn around the call in Raven Pro. For standardization, the time and frequency interval between successive samples was $0.0454 \mathrm{~ms}$ and $10.8 \mathrm{hz}$. (Start: PFC at start; End: PFC at end; Min: Minimal PFC; Q25\%, Q50\%, and Q75\%: Frequency at the $25 \%, 50 \%$, and $75 \%$ energy quantile of the selection; Max: Maximal PFC.)

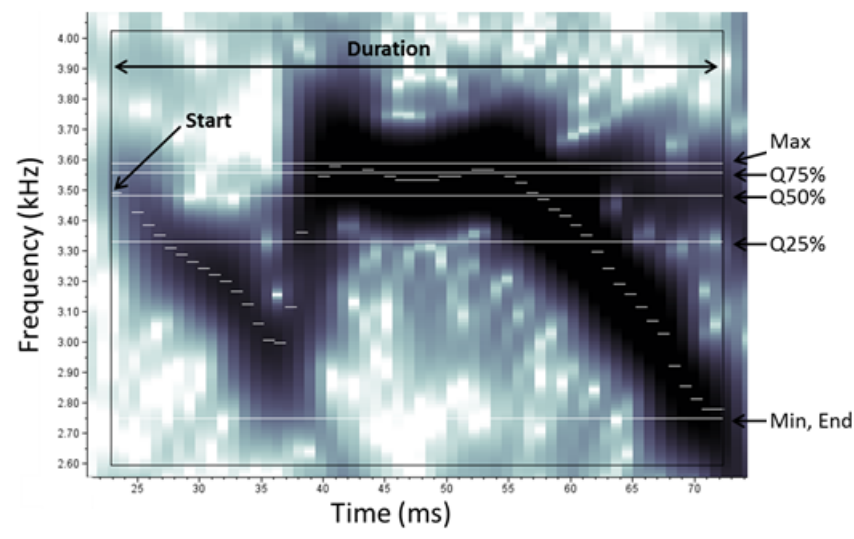

\section{Habitat associations}

To determine habitat at sites with Red Crossbills, we overlaid sites onto digitized habitat layers. An ArcGIS Geoprocessing Wizard (ArcGIS 10.1; ESRI 2012) was used to clip habitat types at sites. Habitat types were established using 1:20,000 forest maps published by the Québec Ministry of Natural Resources in 2012, which were updated to incorporate disturbances, i.e., fires and logging.

\section{RESULTS}

\section{Vocalizations}

Most of the recordings were of medium to low acoustic quality $(n=14)$. Some recordings contained Class I calls with acoustic characteristics that fell within the range of Class I variation of 
Table 1. Descriptive statistics (grand mean $\pm \mathrm{SD}$, range in parentheses) for variables measured on 14 Red Crossbill (Loxia curvirostra) calls recorded on Anticosti Island in June 2014 and 836 Red Crossbill calls recorded in Newfoundland, 4 February 2010-2 August 2011.

\begin{tabular}{lcc}
\hline \hline Acoustic variables & $\begin{array}{c}\text { T8 Anticosti } \\
\left(3^{\dagger}, 14^{\dagger}\right)\end{array}$ & $\begin{array}{c}\text { T8 Newfoundland } \\
(72,836)\end{array}$ \\
\hline Frequency variables (Hz) & & $3767 \pm 330(2870-4708)$ \\
Peak frequency contour (PFC) at start & $3336 \pm 98(3230-3424)$ & $3065 \pm 343(2101-4074)$ \\
PFC at end & $2733 \pm 256(2476-2989)$ & $2909 \pm 214(2061-3363)$ \\
Minimal PFC & $2721 \pm 104(2616-2824)$ & $3406 \pm 189(2676-3920)$ \\
$25 \%$ quantile frequency & $3247 \pm 99(3133-3316)$ & $3581 \pm 185(2816-4082)$ \\
$50 \%$ quantile frequency & $3469 \pm 7(3464-3478)$ & $3740 \pm 194(2959-4316)$ \\
$75 \%$ quantile frequency & $3568 \pm 16(3553-3585)$ & $4116 \pm 299(3508-4841)$ \\
Maximal PFC & $3650 \pm 58(3585-3696)$ & $3512 \pm 177(2772-4056)$ \\
Mean PFC & $3354 \pm 56(3289-3390)$ & \\
Temporal variables (ms) & & $52 \pm 5(41-63)$ \\
Duration & $42 \pm 1(28-51)$ & \\
\hline${ }^{\dagger} n$ individuals & & \\
${ }^{*} n$ calls & & \\
${ }^{\$}$ Newfoundland data from Hynes and Miller (2014) & &
\end{tabular}

Type 8 birds found on the island of Newfoundland (Table 1). Several Class I calls from Anticosti Island had (1) a high degree of modulation, with individual calls containing at least three abrupt frequency changes (e.g., "M-shaped" frequency modulation; Fig. 3A-B); (2) most of the energy concentrated around $3.5 \mathrm{kHz}$; and (3) audible qualities like those of Newfoundland Red Crossbills. Means of three robust quantile frequency measurements fell near the respective values derived from Newfoundland birds, which were previously identified as Type 8 by Hynes and Miller (2014), and standard variation values indicate high overlap between regions and types (Table 1). Interestingly, both the audible qualities and spectrographs of Class I calls also suggest that several other Red Crossbill types may occur on Anticosti Island, i.e., calls without several abrupt frequency changes (Hynes and Miller 2014) that do not resemble the letter "M" (Young et al. 2012). In these cases, calls were more similar to Types 1 and 2, which are two call types known from nearby areas of mainland eastern North America (Fig. 3C-E). Our Anticosti sample also contained some Red Crossbill "song," e.g., groups of sounds with a rhythmic or melodic character. Several song motifs were uttered with short notes and trills similar to those from individuals on the island of Newfoundland (D. Hynes, unpublished data).

\section{Morphological measurements}

LDA classified Red Crossbills based on the combination of bill depth and bill length with an acceptable level of agreement $(\mathrm{K}=$ 0.47 ). The first linear discriminant (LD1), associated with bill depth, explained $92 \%$ of the between-group variance among Red Crossbill specimens (Fig. 4; Table 2). The five Red Crossbill specimens from Anticosti were included in the range of those from Newfoundland and produced a centroid closest to the one representing Newfoundland birds (Fig. 4), which explained the posterior probability of classification of specimens from Anticosti was highest for Newfoundland $(0.58 \pm 0.21)$. Specimens from Newfoundland presented the highest posterior probability of classification for their province $(0.67 \pm 0.24$; Table 3$)$. Figure 5 shows an example of a male Red Crossbill collected on Anticosti.
Fig. 3. Exemplars of Class I calls recorded from Red Crossbills (Loxia curvirostra) Type 8 on (A) Anticosti Island (AI; from this study) and (B) insular Newfoundland (NF; from Hynes and Miller 2014). Some individuals recorded from Anticosti Island resembled Type 2 (C, D; original recordings archived at the Museum of Vertebrate Zoology and the Macaulay Library (catalogue number ML106639), respectively) and Type 1 (E; ML106639) Red Crossbills. Several individuals on (F) Anticosti Island also uttered a song motif with short notes and trills similar to those from individuals on $(\mathrm{G})$ the island of Newfoundland (Hynes and Miller 2014; exemplars from two individuals shown). Each Class I call in the figure represents an individual and vertical bars separate individuals from different regions.

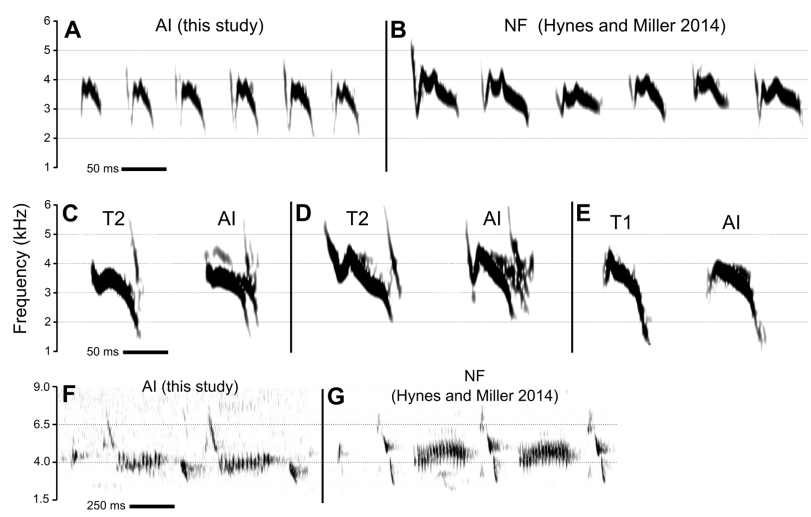

\section{Habitat associations}

Most of the forest stands $(75 \% ; 15 / 20)$ on Anticosti Island with Red Crossbills were dominated or codominated by white spruce while $45 \%(9 / 20)$ where dominated or codominated by balsam fir. 
Table 2. Mean and SD of bill depth and length $(\mathrm{mm})$ of Red Crossbill (Loxia curvirostra) specimens ( $n$ in parentheses) from six different regions.

\begin{tabular}{lcccccc}
\hline \hline & British Columbia & Alberta & Québec & Anticosti & Nova Scotia & Newfoundland \\
& $(26)$ & $(12)$ & $(26)$ & $(5)$ & $(4)$ & $(24)$ \\
\hline Bill depth & $9.1 \pm 0.5$ & $8.3 \pm 0.3$ & $9.3 \pm 0.7$ & $10.2 \pm 0.3$ & $9.4 \pm 0.7$ \\
Bill length & $16.3 \pm 1.4$ & $14.7 \pm 0.8$ & $15.6 \pm 1.7$ & $17.4 \pm 0.7$ & $17.0 \pm 1.5$ & $10.3 \pm 0.8$ \\
\hline
\end{tabular}

Sixty percent (12/20) of forest stands with Red Crossbills were 30 yr stands that originated from past spruce budworm outbreaks (1975-1984). Red Crossbills were observed at four different sites $(20 \% ; 4 / 20)$ that had ongoing spruce budworm defoliation (Fig. 1). Interestingly, one of the birds collected had its crop full of spruce budworm larvae (M. Gosselin, personal communication).

Fig. 4. Scores, centroids (bold dots), and 95\% confidence limits (dashed lines) from a linear discriminant analysis based on bill measurements of Red Crossbill (Loxia curvirostra) specimens from six different regions (AB: Alberta $(n=12)$; AN: Anticosti $(n=5)$; BC: British Columbia $(n=26)$; NF: Newfoundland ( $n$ = 24); NS: Nova-Scotia $(n=4)$; QC: mainland Québec $(n=26)$. The mean and SD of bill measurements can be found in Table 2.

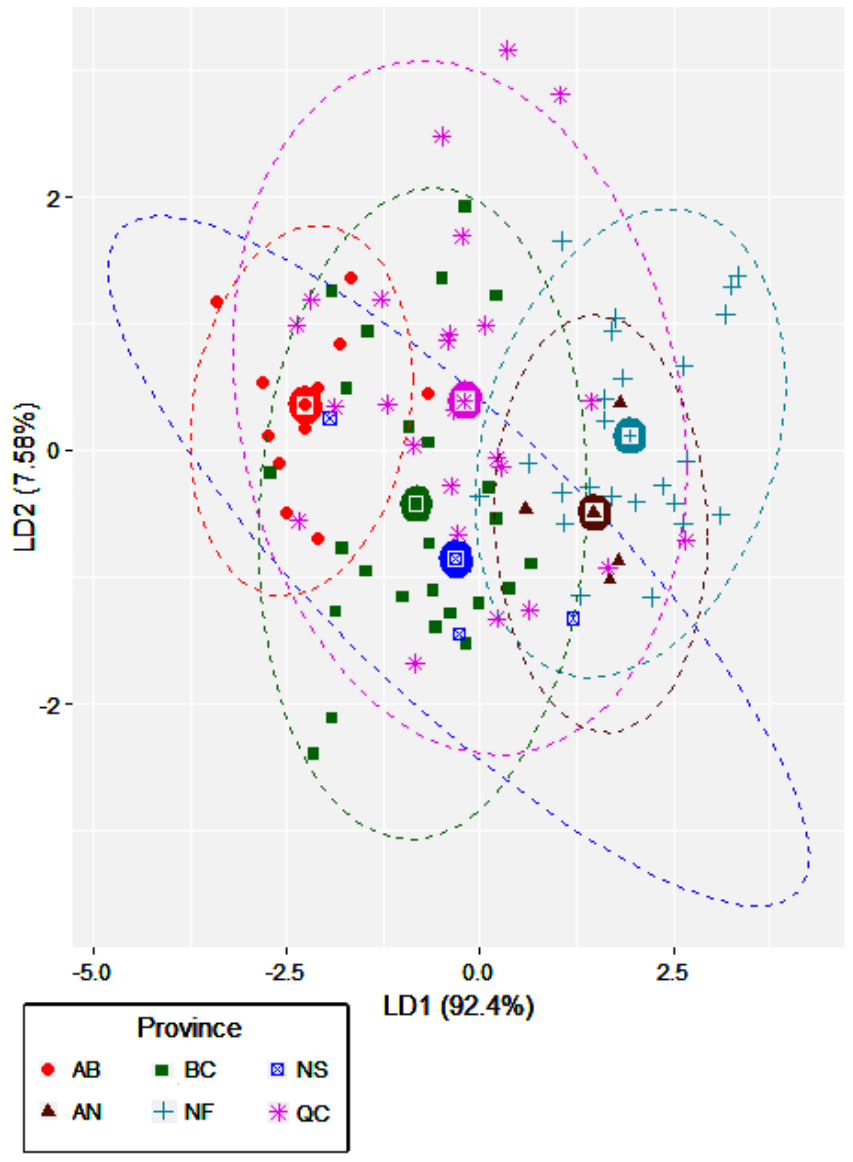

Fig. 5. Photo of a male Red Crossbill (Loxia curvirostra) collected on Anticosti Island during July 2014 (Environment and Climate Change Canada Scientific permit SC-54). Photo by Yann Rochepault.

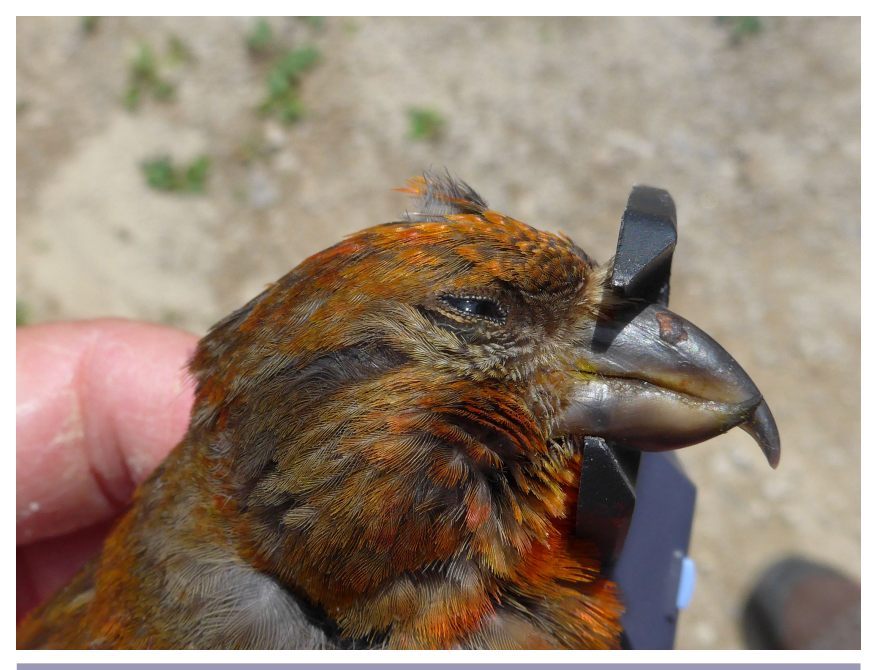

\section{DISCUSSION}

This study documented the presence of adult and juvenile Red Crossbills on Anticosti Island during June 2014 and provided evidence that some of the observed individuals represent $L$. $c$. percna (Type 8). Among the specimens we sampled, bill depth values from Anticosti Red Crossbills were most similar to those of Newfoundland Red Crossbills, percna subspecies (Groth 1993, Benkman 1999, Young et al. 2012), than to those of Red Crossbills from other provinces. Also, some of Anticosti Red Crossbill Class I calls fell within the range of variation of calls from Newfoundland that had been previously described as Type 8 and percna (Young et al. 2012, Hynes and Miller 2014). Our results also suggest that the Anticosti Island may support breeding individuals of percna (and other call types), which has direct consequences on the recovery capability by increasing the known population, and range of this threatened species in Canada.

Although our study is based on limited sample sizes of both morphological and vocalizations, the congruent results from these two distinct data sets strongly suggest establishment of percna Type 8 on Anticosti Island. Some frequency measurements, i.e., mean PFC, which are less sensitive to audio quality recording, fell within the range of Newfoundland individuals, which are vocally distinct from mainland Red Crossbills (Hynes and Miller 2014). Other acoustic variables (nonquantile frequency, duration, 
Table 3. Posterior probabilities of classification (mean $[\mathrm{SD}]$ ) of Red Crossbill (Loxia curvirostra) specimens ( $n$ in parentheses) from a linear discriminant analysis based on bill measurements. Bolded results represent the highest paired associations of a region (by column).

\begin{tabular}{|c|c|c|c|c|c|c|}
\hline & $\begin{array}{c}\text { British-Columbia } \\
(26)\end{array}$ & $\begin{array}{c}\text { Alberta } \\
\text { (12) }\end{array}$ & $\begin{array}{l}\text { Québec } \\
\text { (26) }\end{array}$ & $\begin{array}{l}\text { Anticosti } \\
\text { (5) }\end{array}$ & Nova Scotia (4) & Newfoundland (24) \\
\hline British Columbia & $0.43(0.18)$ & $0.30(0.12)$ & $0.27(0.18)$ & $0.09(0.10)$ & $0.41(0.19)$ & $0.06(0.03)$ \\
\hline Alberta & $0.12(0.17)$ & $0.51(0.22)$ & $0.12(0.20)$ & $0.00(0.00)$ & $0.11(0.21)$ & $0.00(0.00)$ \\
\hline Québec & $0.31(0.20)$ & $0.17(0.14)$ & $0.36(0.24)$ & $0.16(0.12)$ & $0.21(0.06)$ & $0.14(0.14)$ \\
\hline Anticosti & $0.02(0.03)$ & $0.00(0.00)$ & $0.04(0.06)$ & $0.14(0.06)$ & $0.07(0.11)$ & $0.11(0.05)$ \\
\hline Nova Scotia & $0.07(0.05)$ & $0.02(0.01)$ & $0.04(0.04)$ & $0.03(0.02)$ & $0.07(0.06)$ & $0.02(0.02)$ \\
\hline NewFoundland & $0.04(0.06)$ & $0.00(0.00)$ & $0.17(0.27)$ & $0.58(0.21)$ & $0.13(0.21)$ & $0.67(0.24)$ \\
\hline
\end{tabular}

and intensity variables) are more sensitive to recording quality, and these variables may have been degraded by using field recorders of relatively low quality. We highlight the importance, for diagnostic reasons, to obtain high quality recordings of Class I and II calls by using adequate recording equipment. Our recordings were not made with a directional microphone, or a parabola, both of which can increase gain, i.e., amplification of sounds, when birds are relatively far off.

Despite earlier ornithological expeditions to Anticosti Island in 1862 (Verrill 1865), 1881 (Brewster 1883) and 1922 (Lewis 1924), Red Crossbills were not reported there until 1963 (Ouellet 1969). White-winged Crossbills (Loxia leucoptera) were reported for the first time on the island in 1881 (Brewster 1883). The large whitetailed deer population induced habitat changes on the island as early as 1910 , when tree recruitment likely began shifting away from balsam fir and toward white spruce dominance, which later led to further changes in forest stand composition (Potvin et al. 2003). Knowing that age of cone production of white spruce is about 30 yr (Boulet 2013) and that Newfoundland Red Crossbills are suspected to prefer spruce cones when available (Parchman and Benkman 2002), we speculate that the forests of Anticosti may have offered abundant food resources in the 1950s and 1960s. At this time, Red Crossbills may have colonized Anticosti Island if food resources had failed elsewhere (sensu Newton 1967, Smith and Balda 1979, Benkman 1987) and Newfoundland birds may have been forced to disperse in greater numbers once red squirrels, a primary conifer seed consumer, were introduced (Payne 1976). Introduced to insular Newfoundland in the 1960s, red squirrels (Smith 1968, 1970, Steele et al. 2005) are better competitors for cone seeds than Red Crossbills (Benkman 2010). Furthermore, cones on Anticosti may have characteristics favoring colonization of percna given that cones there coevolved in an environment free of squirrels (Benkman 1987). Accordingly, Red Crossbills are more efficient in foraging on closed cones than White-winged Crossbills and the predicted foraging efficiency of percna is higher than other Red Crossbills mainly based on the size of its bill (Benkman 1987). Thus, we speculate large-billed crossbills like percna may have had an advantage over other colonizers of Anticosti Island, e.g., White-winged Crossbills or other Red Crossbill taxa, when foraging on a seed resource consisting of mostly closed conifer cones. Evidence that such a scenario may have occurred can be seen in the relative changes in abundance of Red Crossbill and White-winged Crossbill by other observers. For example, in the early 2010s, there was a coinciding decrease in White-winged Crossbills and an increase of Red Crossbills on the island during the second breeding atlas of Québec (Québec
Breeding Bird Atlas 2016). Further, Red Crossbills were among the most abundant bird species on Anticosti during ornithological excursions in July 2016, while White-winged Crossbills were relatively uncommon (B. Drolet and J. Ibarzabal, all checklists are available on eBird).

We expected Red Crossbills to be associated with mature forest stands, but most of our Red Crossbill observations occurred in relatively young forests stands dominated by white spruce, although we acknowledge that we surveyed only the central region of the island. Indeed, a recent study reported that Red Crossbills are indicators of mature conifer forests with high deer density on Anticosti Island (Bachand et al. 2014). Although our results are not congruent with Bachand et al. (2014), spruce budworm infestations during our survey may have influenced foraging behaviors of Red Crossbills. Accordingly, 20\% of Red Crossbill observations occurred in forest stands mapped as infested by spruce budworms, and up to $75 \%$ of observations were within 1 $\mathrm{km}$ of mapped infested stands. Furthermore, one of the three Red Crossbills collected had its crop full of spruce budworm larvae. Impacts of spruce budworm outbreaks on Red Crossbill populations have been described in a negative light because outbreaks reduce the extent of mature forests at the regional scale (sensu Bolgiano 2004). However, as we observed, Red Crossbills may benefit from outbreaks by feeding on larvae during infestations. Further study is needed to better understand the short and medium term relationships between spruce budworm outbreaks and Red Crossbill populations.

\section{CONCLUSION}

Our results may have important conservation implications for the recovery and persistence of percna because the Newfoundland population is thought to be relatively small and the subspecies faces major threats. Some Red Crossbill populations exhibit densities up to 20 times higher in the absence of red squirrels (Benkman 2010), and Anticosti Island may act as refugia for percna (Type 8). Further baseline studies are needed to better understand the population dynamics of Red Crossbills on Anticosti Island, especially with respect to percna; levels of demographic and genetic exchange between Newfoundland and Anticosti Island populations; and the relative proportions of Red Crossbill types on Anticosti. Urgently needed are baseline studies that aim to define the relationship between morphometric measurements of percna and their Class I calls. To do this, physical and vocal data need to be collected from individual birds. 
Responses to this article can be read online at:

http://www.ace-eco.org/issues/responses.php/1175

\begin{abstract}
Acknowledgments:
We are thankful to Yann Rochepault and Christophe Buidin for leading the field sampling on Anticosti Island in July 2014, and to Yves Aubry and Charles Francis for their observations of Red Crossbills made in June 2014. Special thanks to Michel Gosselin and Gregory Rand of the Canadian Museum of Nature in Ottawa for providing access to specimens and for the necropsy of the three Red Crossbills collected in July 2014. Thank you to the SÉPAQAnticosti for their logistical support.
\end{abstract}

\section{LITERATURE CITED}

Adkisson, C. S. 1996. Red Crossbill (Loxia curvirostra), version 2.0. In P. G. Rodewald, editor. The birds of North America. Cornell Lab of Ornithology, Ithaca, New York, USA. http://dx. doi.org/10.2173/bna.256

Bachand, M., S. Pellerin, S. D. Côté, M. Moretti, M. De Cáceres, P. M. Brousseau, C. Clautier, C. Hébert, É. Cardinal, J.-L. Martin, and M. Poulin. 2014. Species indicators of ecosystem recovery after reducing large herbivore density: comparing taxa and testing species combinations. Ecological Indicators 38:12-19. http://dx. doi.org/10.1016/j.ecolind.2013.10.018

Benkman, C. W. 1987. Food profitability and the foraging ecology of crossbills. Ecological Monographs 57:251-267. http://dx.doi. org/10.2307/2937083

Benkman, C. W. 1989. On the evolution and ecology of island populations of crossbills. Evolution 43:1324-1330. http://dx.doi. org/10.1111/j.1558-5646.1989.tb02581.x

Benkman, C. W. 1993. Adaptation to single resources and the evolution of crossbill (Loxia) diversity. Ecological Monographs 63:305-325. http://dx.doi.org/10.2307/2937103

Benkman, C. W. 1999. The selection mosaic and diversifying coevolution between crossbills and lodgepole pine. American Naturalist 153:S75-S91. http://dx.doi.org/10.1086/303213

Benkman, C. W. 2003. Divergent selection drives the adaptive radiation of crossbills. Evolution 57:1176-1181. http://dx.doi. org/10.1111/j.0014-3820.2003.tb00326.x

Benkman, C. W. 2010. Diversifying coevolution between crossbills and conifers. Evolution: Education and Outreach 3:47-53. http://dx.doi.org/10.1007/s12052-009-0190-8

Benkman, C. W., W. C. Holimon, and J. W. Smith. 2001. The influence of a competitor on the geographic mosaic of coevolution between crossbills and lodgepole pine. Evolution 55:282-294. http://dx.doi.org/10.1111/j.0014-3820.2001.tb01293. $\mathrm{x}$

Benkman, C. W., T. L. Parchman, and A. M. Siepielski. 2008. The geographic mosaic of coevolution and its conservation significance. Conservation Biology: Evolution in Action 1:225.
Benkman, C. W., J. W. Smith, P. C. Keenan, T. L. Parchman, and L. Santisteban. 2009. A new species of the Red Crossbill (Fringillidae: Loxia) from Idaho. Condor 111:169-176. http://dx. doi.org/10.1525/cond.2009.080042

Bent, A. C. 1912. A new subspecies of crossbill from Newfoundland. Smithsonian Miscellaneous Collections 60:1-3.

Bioacoustics Research Program. 2014. Raven Pro: interactive sound analysis software (Version 1.5). The Cornell Lab of Ornithology, Ithaca, New York, USA. [online] URL: http://www. birds.cornell.edu/raven

Bolgiano, N. C. 2004. Changes in boreal bird irruptions in eastern North America relative to the 1970s spruce budworm infestation. American Birds 54:26-33.

Boulet, B. 2013. Synthèse des connaissances sur l'écologie des conifères. Pages 152-179 in B. Boulet and M. Huot, editors. Le guide sylvicole du Québec. Les publications du Québec, Québec, Canada.

Brewster, W. 1883. Notes on the birds observed during a summer cruise in the Gulf of St. Lawrence. Proceedings of the Boston Society of Natural History XXII:364-412.

Chesser, T. R., K. J. Burns, C. Cicero, J. L. Dunn, A. W. Kratter, I. J. Lovette, P. C. Rasmussen, J. V. Rensen Jr., J. D. Rising, D. F. Stotz, and K. Winker. 2017. Fifty-eighth supplement to the American Ornithological Society's Check-list of North American Birds. Auk 134:751-773. http://dx.doi.org/10.1642/AUK-17-72.1

Chouinard, A., and L. Filion. 2005. Impact of introduced whitetailed deer and native insect defoliators on the density and growth of conifer saplings on Anticosti Island, Québec. Écoscience 12:506-518. http://dx.doi.org/10.2980/i1195-6860-12-4-506.1

Cohen, J. 1960. A coefficient of agreement for nominal scales. Educational and Psychological Measurement 20:37-46. http://dx. doi.org/10.1177/001316446002000104

Committee on the Status of Endangered Wildlife in Canada (COSEWIC). 2016. COSEWIC assessment and status report on the Red Crossbill percna subspecies Loxia curvirostra percna in Canada. COSEWIC, Ottawa, Ontario, Canada. [online] URL: http://www.sararegistry.gc.ca/default.asp?lang=En\&n=0D3A8709-1

Darveau, M., L. Bélanger, J. Huot, É. Mélançon, and S. DeBellefeuille. 1997. Forestry practices and the risk of bird nest predation in a boreal coniferous forest. Ecological Applications 7:572-580. http://dx.doi.org/10.1890/1051-0761(1997)007[0572: FPATRO]2.0.CO;2

Edelaar, P. 2008. Assortative mating also indicates that common crossbill Loxia curvirostra vocal types are species. Journal of Avian Biology 39:9-12. http://dx.doi.org/10.1111/j.0908-8857.2008.04231. $\mathrm{X}$

ESRI. 2012. ArcGIS Desktop: Release 10.1. Environmental Systems Research Institute, Redlands, California, USA.

Groth, J. G. 1993. Evolutionary differentiation in morphology, vocalizations, and allozymes among nomadic sibling species in the North American Red Crossbill (Loxia curvirostra) complex. University of California Publications in Zoology 127:1-143. 
Hynes, D. P., and E. H. Miller. 2014. Vocal distinctiveness of the Red Crossbill (Loxia curvirostra) on the island of Newfoundland, Canada. Auk 131:421-433. http://dx.doi.org/10.1642/AUK-13-224.1

Izenman, A. J. 2013. Linear discriminant analysis. Pages 237-280 in Modern multivariate statistical techniques. Springer, New York, New York, USA. http://dx.doi.org/10.1007/978-0-387-78189-1_8

Knox, A. G. 1992. Species and pseudospecies: the structure of crossbill populations. Biological Journal of the Linnean Society 47:325-335. http://dx.doi.org/10.1111/j.1095-8312.1992.tb00673. $\mathrm{x}$

Kuhn, M., J. Wing, S. Weston, A.Williams, C. Keefer, A. Engelhardt, T. Cooper, Z. Mayer, B. Kenkel, M. Benesty, R. Lescarbeau, A. Ziem, L. Scrucca, Y. Tang, C. Candan, and T Hunt. 2017. Classification and regression training. [online] URL: https://cran.r-project.org/web/packages/caret/caret.pdf

Létourneau, V. 1995. Le Bec-croisé des sapins. Pages 1066-1069 in J. Gauthier and Y. Aubry, editors. Les Oiseaux nicheurs $d u$ Québec: Atlas des oiseaux nicheurs du Québec méridional. Association québécoise des groupes d'ornithologues, Province du Québec, Société de protection des oiseaux, Service canadien de la faune, Environnement Canada, Région de Québec, Montréal, Québec, Canada.

Lewis, H. F. 1924. List of birds recorded from the Island of Anticosti, Quebec. Canadian Field-Naturalist 38:43-46.

Ministère des Forêts, de la Faune et des Parcs du Québec (MFFP). 2015. Aires infestées par la tordeuse des bourgeons de l'épinette au Québec en 2014 - Version 1.2. Direction de la protection des forêts. MFFP, Québec, Québec, Canada.

Ministère des Ressources naturelles et de la Faune du Québec (MRNF). 2012. Aires infestées par l'arpenteuse de la pruche au Québec en 2012 - Version 1.0. Direction de la protection des forêts. MRNF, Québec, Québec, Canada.

Newton, I. 1967. The adaptive radiation and feeding ecology of some British finches. Ibis 109:33-96. http://dx.doi.org/10.1111/ j.1474-919X.1967.tb00005.X

Ouellet, H. 1969. Les oiseaux de l'île Anticosti, province de Québec, Canada. Musée national des sciences naturelles, Publications en zoologie no1. Ottawa, Ontario, Canada.

Parchman, T. L., and C. W. Benkman. 2002. Diversifying coevolution between crossbills and black spruce on Newfoundland. Evolution 56:1663-1672. http://dx.doi.org/10.1111/ j.0014-3820.2002.tb01478.x

Parchman, T. L., C. W. Benkman, and S. C. Britch. 2006. Patterns of genetic variation in the adaptive radiation of New World crossbills (Aves: Loxia). Molecular Ecology 15:1873-1887. http:// dx.doi.org/10.1111/j.1365-294X.2006.02895.x

Payne, N. F. 1976. Red squirrel introduction to Newfoundland. Canadian Field-Naturalist 90:60-64.

Payne, R. B. 1987. Populations and type specimens of a nomadic bird: comments on the North American Crossbills Loxia pusilla Glober 1834 and Crucirostra minor Brehm 1845. Occasional Paper of the Museum of Zoology Number 714. University of Michigan, Ann Arbor, Michigan, USA.
Potvin, F., P. Beaupré, and G. Laprise. 2003. The eradication of balsam fir stands by white-tailed deer on Anticosti Island, Québec: a 150-year process. Ecoscience 10:487-495. http://dx.doi. org/10.1080/11956860.2003.11682796

Québec Breeding Bird Atlas. 2016. Atlas results (maps). Québec Breeding Bird Atlas, Québec, Québec, Canada. [online] URL: http://www.atlas-oiseaux.qc.ca/donneesqc/cartes.jsp?lang=en

R Core Team. 2015. R: A language and environment for statistical computing. R Foundation for Statistical Computing, Vienna, Austria. [online] URL:http://www.R-project.org/

Reitsma, L. R., R. T. Holmes, and T. W. Sherry. 1990. Effects of removal of red squirrels, Tamiasciurus hudsonicus, and eastern chipmunks, Tamias striatus, on nest predation in a northern hardwood forest: an artificial nest experiment. Oikos 57:375-380. http://dx.doi.org/10.2307/3565967

Ripley, B., B. Venables, D. M. Bates, K. Hornik, A. Gebhardt, and D. Firth. 2016. Support functions and datasets for Venables and Ripley's MASS. [online] URL: https://cran.r-project.org/ web/packages/MASS/MASS.pdf

Rochette, B., and A. Gingras. 2007. Inventaire aérien du cerf de Virginie de l'île d'Anticosti - Été 2006. Ministère des Ressources naturelles et de la Faune, Direction de l'aménagement de la faune de la Côte-Nord, Québec, Canada.

Saucier, J. P., J. F. Bergeron, P. Grondin, and A. Robitaille. 1998. Les zones de végétation et les domaines bioclimatiques du Québec. Ministère des Ressources naturelles du Québec, Forêts Québec, Sainte-Foy, Québec, Canada.

Schluter, D. 2001. Ecology and the origin of species. Trends in Ecology and Evolution 16:372-380. http://dx.doi.org/10.1016/ S0169-5347(01)02198-X

Sewall, K. B. 2009. Limited adult vocal learning maintains call dialects but permits pair-distinctive calls in Red Crossbills. Animal Behaviour 77:1303-1311. http://dx.doi.org/10.1016/j.anbehav.2009.01.033

Sewall, K. B. 2011. Early learning of discrete call variants in Red Crossbills: implications for reliable signaling. Behavioral Ecology and Sociobiology 65:157-166. http://dx.doi.org/10.1007/s00265-010-1022-0

Smith, C. C. 1970. The coevolution of pine squirrels (Tamiasciurus) and conifers. Ecological Monographs 40:349-371. http://dx.doi.org/10.2307/1942287

Smith, C. C., and R. P. Balda. 1979. Competition among insects, birds and mammals for conifer seeds. American Zoologist 19:1065-1083. http://dx.doi.org/10.1093/icb/19.4.1065

Smith, M. C. 1968. Red Squirrel responses to spruce cone failure in interior Alaska. Journal of Wildlife Management 32:305-317. http://dx.doi.org/10.2307/3798975

Steele, M. A., L. A. Wauters, and K. W. Larsen. 2005. Selection, predation and dispersal of seeds by tree squirrels in temperate and boreal forests: are tree squirrels keystone granivores? Pages 205-221 in P. M. Forget, J. E. Lambert, P. E. Hulme, and S. B. Vander Wall, editors. Seed fate: predation, dispersal and seedling establishment. CAB International, Wallingford, UK. http://dx. doi.org/10.1079/9780851998060.0205 
Tremblay, J.-P., I. Thibault, C. Dussault, J. Huot, and S. D. Côté. 2005. Long-term decline in white-tailed deer browse supply: can lichens and litterfall act as alternative food sources that preclude density-dependent feedbacks? Canadian Journal of Zoology 83:1087-1096. http://dx.doi.org/10.1139/z05-090

Verrill, A. E. 1865. Notes on the natural history of Anticosti. Proceedings of the Boston Society of Natural History IX:132-143.

Young, M. A., D. A. Fifield, and W. A. Montevecchi. 2012. New evidence in support of a distinctive Red Crossbill (Loxia curvirostra) type in Newfoundland. North American Birds 66:29-33.

Young, M., and T. Spahr. 2017. Crossbills of North America: species and Red Crossbill call types. eBird. [online] URL: http:// ebird.org/content/ebird/news/crossbills-of-north-america-speciesand-red-crossbill-call-types 